\title{
SISTEMA CARCERÁRIO BRASILEIRO E SISTEMA INTERAMERICANO DE PROTEÇÃO DOS DIREITOS HUMANOS: a análise do Caso Urso Branco sob o prisma do Direito à Saúde
}

\author{
Cinthia de Cerqueira Alves ${ }^{1}$ \\ Márcia Costa Misi
}

\begin{abstract}
RESUMO
Este artigo pretende avaliar o modo como ocorre a implementação das decisões da Corte Interamericana de Direitos Humanos no Brasil, especificamente, no que tange ao sistema prisional. Com o intuito cumprir esse objetivo foi selecionado o Caso Urso Branco, alvo de diversas medidas provisórias emitidas pela Corte. Este caso trata da situação de uma penitenciária localizado no Estado de Rondônia onde foram perpetradas graves violações de direitos humanos, com a ocorrência do segundo maior massacre da história prisional brasileira. Com a análise dos relatórios emitidos pela Corte Interamericana em relação ao Caso referido, constatamos que uma ampla gama de direitos fora desrespeitada pelo Estado Brasileiro. Diante da amplitude das violações, foi necessário escolher uma vertente específica para análise: o acesso à saúde no sistema prisional, que ainda é uma questão não resolvida pelo Estado Brasileiro. Assim, verificou-se as ações estatais tomadas para implementar as determinações da Corte bem assim os obstáculos encontrados no processo de efetivação das determinações deste órgão frente às peculiaridades da realidade brasileira.
\end{abstract}

Palavras-chave: Direito internacional. Corte interamericana. Sistema penitenciário brasileiro.

\section{INTRODUÇÃO}

As recorrentes violações de direitos humanos perpetradas pelos Estados contra seus cidadãos têm ensejado, desde o princípio do século $\mathrm{XX}$, a criação de mecanismos internacionais de tutela dos direitos humanos. Nesse contexto, destacamos o Sistema Interamericano de Proteção dos Direitos Humanos, composto pela Comissão e pela Corte.

A Corte, objeto de análise desta pesquisa, é um órgão judicial autônomo, dotado de funções consultiva e contenciosa, responsável pela interpretação e aplicação da Convenção Interamericana, documento em torno do qual orbita o Sistema Interamericano.

\footnotetext{
${ }^{1}$ Graduanda em Direito da Universidade Estadual de Feira de Santana. Bolsista FAPESB.

${ }^{2}$ Orientadora, Professora Mestra, vinculada à Universidade Estadual de Feira de Santana.
} 
Dentre as competências deste Tribunal está a emissão de medidas provisórias em casos de flagrante violação aos direitos humanos. Tais medidas são regidas pelo princípio da efetividade e constituem garantias jurisdicionais de caráter preventivo em relação a uma coletividade, evitando o agravamento de lesões aos direitos humanos.

A presente pesquisa gravita em torno do modo de implementação das medidas provisórias emitidas pela Corte Interamericana em relação ao Brasil, a fim de aferir qualitativamente a facticidade dessas medidas como fatores de coerção frente às instâncias políticas e judiciais do país.

As análises referidas foram realizadas a partir do caso que foi alvo de medidas provisórias emanadas pela Corte Interamericana de Direitos Humanos, e está relacionado às violações de direitos humanos cometidas na Casa de Detenção José Mário Alves, conhecida como Presídio Urso Branco, localizada no estado de Rondônia. Dentro dessa unidade prisional ocorreram vários episódios de tortura e homicídios perpetrados pelos presos e pelos agentes penitenciários, há também um contexto de superlotação e falta de bens e serviços básicos, como água, medicamentos, produtos de higiene e atendimento médico.

Propõe-se, dessa forma, avaliar como se opera o modelo de coerção internacional frente ao direito interno no Brasil, analisando uma situação específica (o desrespeito aos direitos humanos no sistema carcerário), a partir de um caso concreto apreciado pela Corte Interamericana de Direitos Humanos (Caso Urso Branco).

No primeiro momento, foi realizado o levantamento de todas as medidas provisórias emitidas pela Corte Interamericana no caso Urso Branco, a fim de medir qualitativamente quais ações tomadas pelo governo brasileiro a fim de mudar as calamidades denunciadas pela Corte. Constatou-se que uma variedade de direitos fora desrespeitada pelo Estado brasileiro. Diante dessa amplitude de violações, surgiu a necessidade de fracionar linhas temáticas, realizando a análise específica do cumprimento do direito à saúde no sistema prisional, segundo as determinações da Corte e as peculiaridades da realidade brasileira, com a indicação das principais dificuldades encontradas na consecução da implementação.

\section{O SISTEMA INTERAMERICANO DE PROTEÇÃO DOS DIREITOS HUMANOS}


No II pós-guerra, diante das atrocidades perpetradas pelos Estados contra os seus próprios nacionais, os direitos humanos ganharam relevância internacional, não podendo mais ser enunciados como direitos deste ou daquele Estado. Tais direitos passaram a ostentar um status internacional, Direitos Humanos inerentes à pessoa humana, de cunho universal, indivisível e dimensão cosmopolita.

A ação dos regimes totalitaristas demonstrou que não bastava enunciar a existência dos Direitos Humanos, era preciso engendrar mecanismos que garantissem sua aplicação e efetividade em âmbito mundial. Nas palavras de Thomas Buergenthal ${ }^{3}$ :

\begin{abstract}
O moderno Direito Internacional dos Direitos Humanos é um fenômeno do pós-guerra. Seu desenvolvimento pode ser atribuído às monstruosas violações de direitos humanos da era Hitler e à crença de que parte destas violações poderiam ser prevenidas se um efetivo sistema de proteção internacional de direitos humanos existisse.
\end{abstract}

No pós-guerra, desenhou-se, portanto, “o esforço de reconstrução dos direitos humanos, como paradigma e referencial ético a orientar a ordem internacional contemporânea"4.

Nesse sentido, a Organização das Nações Unidas (ONU) foi fundada por cinquenta países, dentre os quais o Brasil, em 1945, durante a Conferência de São Francisco. A ONU instituiu diversos documentos com o fito de assegurar a tutela dos Direitos Humanos internacionalmente, dentre tais documentos, destacam-se: a Declaração Universal dos Direitos Humanos (1948), o pacto dos direitos civis e políticos (1966), o pacto dos direitos econômicos e sociais (1966), e, ainda, a Convenção para a Repressão do Crime de Genocídio (1948), a Convenção Contra a Tortura e Outros Tratamentos ou Penas Cruéis, Desumanos ou Degradantes, entre outros.

Tendo como inspiração um ponto comum, ou seja, a Declaração Universal dos Direitos Humanos de 1948, foram engendrados sistemas regionais de proteção dos Direitos Humanos, nesse sentido, há que ser referida a Convenção Europeia de Direitos Humanos adotada em 04 de novembro de 1950.

No continente americano, foram editadas a Declaração Americana de Direitos e Deveres do Homem e a Carta Internacional Americana de Garantias Sociais, ambas no

\footnotetext{
${ }^{3}$ PIOVESAN, Flávia. Direitos Humanos e o Direito Constitucional Internacional. 14. ed., rev. e atual. São Paulo : Saraiva, 2013. p. 119.

${ }^{4}$ PIOVESAN, Flávia. Direitos Humanos e o Direito Constitucional Internacional. 14. ed., rev. e atual. São Paulo : Saraiva, 2013. p. 120.
} 
ano de 1948. Mais tarde, tal sistema será consolidado com a adoção da Convenção Americana sobre Direitos Humanos em 1969, documento base deste sistema regional.

Ainda em caráter regional, foi criado o sistema Africano de proteção, em 1982, com a edição da Carta dos Direitos Humanos e dos Povos. É importante ressaltar que, embora tardiamente criado, o sistema Africano representa grande avanço no panorama da efetivação dos direitos humanos, considerando as graves violações experimentadas no período de colonização e a descolonização tardia, que ocorreu no II pós-guerra.

Adicionalmente, há ainda um incipiente sistema árabe e a proposta de criação de um sistema regional asiático.

Ultrapassando a mera enunciação dos direitos humanos através de tratados e convenções, surgiu a ideia de dotar os sistemas de proteção de uma jurisdição supra estatal de caráter perene ${ }^{5}$. Nesse sentido, os sistemas regionais de proteção estabeleceram cortes no seu âmbito a fim de julgar violações de direitos humanos. Note-se que o Sistema global ONU não possui uma corte especializada para o julgamento de violações contra os direitos humanos.

O Sistema interamericano de Proteção dos Direitos Humanos possui uma Corte especializada no julgamento de violações de direitos humanos previstos na Convenção Americana de 1969.

\subsection{A estrutura do sistema interamericano de proteção dos direitos humanos}

A essência do sistema internacional de proteção dos direitos humanos consiste em somar, aperfeiçoar e proteger integralmente a pessoa humana. Assim, os diversos sistemas coexistem em benefício do indivíduo.

Os sistemas internacionais de proteção dos direitos humanos, em especial o interamericano, são instrumentos eficazes de proteção e de promoção dos direitos humanos, quando as instituições domésticas dos Estados se mostram ineficientes em coibir violações a direitos humanos. Realmente, cabe aos Estados, primeiramente, promover e proteger em seu âmbito interno, os direitos humanos e, caso os Estados não se desincumbam plenamente desse ônus, caberá aos órgãos dos sistemas internacionais

\footnotetext{
${ }^{5}$ SANTOS, Alberto Silva. A internacionalização dos Direitos Humanos e o Sistema Interamericano
} de Proteção. Belo Horizonte: Arraes editores, 2012. p. 94. 
de proteção dos direitos humanos garantirem o respeito aos direitos consagrados nos tratados internacionais.

O Sistema Interamericano de Proteção dos Direitos Humanos faz parte da Organização dos Estados Americanos - OEA, a qual já estava sendo concebida ao final do século XIX, porém só a partir do pós-guerra, começou-se a se discutir a criação de um sistema no âmbito americano que tivesse o fito de manutenção da paz e relacionamento entre Estados do continente. Assim, em 1948, foi assinado o Pacto de Bogotá, criando, efetivamente, a Organização dos Estados Americanos.

Gradativamente, adotando diferentes instrumentos internacionais, os Estados Americanos, por meio da Organização dos Estados Americanos (OEA), estruturaram um sistema regional americano de promoção e proteção dos direitos humanos.

Tal sistema regional de promoção e proteção dos direitos humanos é composto por dois órgãos: Comissão Interamericana de Direitos Humanos e da Corte Interamericana de Direitos Humanos.

No que tange à evolução da conformação deste sistema Cançado Trindade ${ }^{6}$ diz:

[...] atualmente identificam-se cinco etapas básicas: a primeira, dos antecedentes do sistema, encontrou-se marcada pela mescla de instrumentos de conteúdo e efeitos jurídicos variáveis; a segunda, de formação do sistema interamericano de proteção, caracterizou-se pelo papel solitariamente primordial da Comissão Interamericana de Direitos Humanos e pela expansão gradual das faculdades da mesma; a terceira, de institucionalização convencional do sistema, evoluiu a partir da entrada em vigor da Convenção Americana sobre Direitos Humanos; a quarta etapa, a partir do início da década de 1980, corresponde à consolidação do sistema, mediante a evolução da jurisprudência da Corte Interamericana de Direitos Humanos e também a adoção de novos instrumentos de proteção; e dos anos 1990 aos anos 2000 ingressamos em uma quinta etapa, que corresponde à do fortalecimento do sistema interamericano de proteção aos direitos humanos.

Importante salientar que o caráter complementar do Sistema Interamericano em relação ao Sistema Global. Nesse sentido, Alberto Santos ${ }^{7}$ afirma que “o Sistema Interamericano de Direitos Humanos, como sistema regional que é, age de forma

\footnotetext{
6 TRINDADE, Antonio Augusto Cançado. Tratado de Direito Internacional dos Direitos Humanos, volume III, Ed. Sergio Antonio Fabris Editor, pp. 30 a 32. In MIRANDA, Mariana Almeida Picanço de; CUNHA, José Ricardo. Poder Judiciário Brasileiro E A Proteção Dos Direitos Humanos: Aplicabilidade e incorporação das decisões da Corte Interamericana de Direitos Humanos. Rio de Janeiro: Escola de Direito do Rio de Janeiro da Fundação Getúlio Vargas, Centro de Justiça e Sociedade, 2010. p. 26-27.

7 SANTOS, Alberto Silva. A internacionalização dos Direitos Humanos e o Sistema Interamericano de Proteção. Belo Horizonte: Arraes editores, 2012.p. 101.
} 
conjunta, complementar com o Sistema Global. As normas que versem sobre Direitos Humanos editadas pelo Sistema se situam num plano vertical com o Direito Interno e num plano horizontal com o Sistema Global, prevalecendo sempre o critério da norma mais favorável em matéria de Direitos Humanos".

\subsection{Pacto de São José da Costa Rica}

Em 12 de fevereiro de 1969, durante uma conferência da Organização dos Estados Americanos (OEA) realizada na Costa Rica, os países-membros da OEA adotaram um tratado internacional multilateral: a Convenção Americana de Direitos Humanos, também conhecida por "Pacto de San José da Costa Rica", já que nesta cidade foi realizada a Conferência, sendo considerado o instrumento mais importante do sistema interamericano.

Contudo, o Pacto de São José da Costa Rica só entrou em vigor em 1978, quando o décimo primeiro Estado ratificou esse tratado. O Brasil ratificou e incorporou internamente a Convenção Americana de Direitos Humanos em 1992.

Dentre as disposições da Convenção, cabe citar trecho do seu preâmbulo que ratifica o duplo caráter complementar do Sistema Regional, já que este funciona como instância de suplementação do Sistema Global e da jurisdição dos Estados Partes:

\footnotetext{
Reconhecendo que os direitos essenciais do homem não derivam do fato de ser ele nacional de determinado Estado, mas sim do fato de ter como fundamento os atributos da pessoa humana, razão por que justificam uma proteção internacional, de natureza convencional, coadjuvante ou complementar da que oferece o direito interno dos Estados americanos.
}

O Pacto de São José prevê, ainda, as atribuições de cada um dos órgãos do Sistema Interamericano, especialmente a Comissão e a Corte. Tais órgãos também possuem seu funcionamento regido pelos seus regulamentos internos, os quais foram remodelados e estão em vigor desde outubro de 2006 e janeiro de 2009 (Regimentos da Comissão e da Corte, respectivamente).

No sentido de compreender como o Sistema Interamericano funciona em relação a Estados Federais, como o Brasil, o Pacto, no art. 28, traz uma cláusula federativa. Essa cláusula firma o entendimento de que recai sobre a União, em caso de Estados Federais, a responsabilidade pelo cumprimento das disposições da Convenção, 
ainda que a violação tenha sido perpetrada por um Estado-membro da União. Essa informação é importante para entender as questões que envolvem a implementação das Medidas Provisionais no Brasil ${ }^{8}$, foco de análise dessa pesquisa. Vejamos o dispositivo da Convenção:

\begin{abstract}
Artigo 28. Cláusula federal
1. Quando se tratar de um Estado Parte constituído como Estado federal, o governo nacional do aludido Estado Parte cumprirá todas as disposições da presente Convenção, relacionadas com as matérias sobre as quais exerce competência legislativa e judicial.

2. No tocante às disposições relativas às matérias que correspondem à competência das entidades componentes da federação, o governo nacional deve tomar imediatamente as medidas pertinente, em conformidade com sua constituição e suas leis, a fim de que as autoridades competentes das referidas entidades possam adotar as disposições cabíveis para o cumprimento desta Convenção.

3. Quando dois ou mais Estados Partes decidirem constituir entre eles uma federação ou outro tipo de associação, diligenciarão no sentido de que o pacto comunitário respectivo contenha as disposições necessárias para que continuem sendo efetivas no novo Estado assim organizado as normas da presente Convenção.
\end{abstract}

Cumpre informar que nem todos os Estados membros da OEA ratificaram o Pacto de São José, sendo que dos 35 membros da OEA, apenas 24 são membros da Convenção.

Observe-se, ainda, que a Convenção Americana de Direitos Humanos é o único tratado internacional de direitos humanos que estabelece medidas preliminares ou provisórias judicialmente aplicáveis 9 .

O Sistema Interamericano, além do seu documento base, conta com outros instrumentos que protegem direitos específicos, tais como a Convenção Interamericana para Prevenir e Punir o Crime de Tortura, o Protocolo Adicional à Convenção Americana de Direitos Humanos relativo à Abolição de Pena de Morte e a Convenção Interamericana para Prevenir, Punir e Erradicar a Violência contra a Mulher, entre outros. Citam-se como o mais importante deles o Protocolo Adicional à Convenção Americana de Direitos Humanos em matéria de Direitos Econômicos, Sociais e Culturais (ou Protocolo de San Salvador), ratificado pelo Brasil em 1996.

\footnotetext{
${ }^{8}$ SANTOS, Alberto Silva. A internacionalização dos Direitos Humanos e o Sistema Interamericano de Proteção. Belo Horizonte: Arraes editores, 2012.p. 104.

${ }^{9}$ MIRANDA, Mariana Almeida Picanço de; CUNHA, José Ricardo. Poder Judiciário Brasileiro E A Proteção Dos Direitos Humanos: Aplicabilidade e incorporação das decisões da Corte Interamericana de Direitos Humanos. Rio de Janeiro: Escola de Direito do Rio de Janeiro da Fundação Getúlio Vargas, Centro de Justiça e Sociedade, 2010. p 28.
} 


\subsection{A Comissão Interamericana de Direitos Humanos}

A Comissão surgiu em 1959, antes da edição da Convenção Interamericana, com a função de promover os Direitos Humanos. Este órgão possui dupla vinculação, já que está previsto e se submete aos regulamentos tanto da Carta da OEA quanto da Convenção Americana sobre Direitos Humanos.

A Comissão possui competência sobre todos os membros da OEA, ainda que não tenham ratificado o Pacto de São José, bastando a vinculação à Declaração Americana dos Direitos e Deveres do Homem (1948).

É composta por sete membros, eleitos pela Assembleia Geral para mandatos de quatro anos, permitida uma reeleição. Os eleitos são representantes não de seus próprios países, mas de todos os Estados membros da OEA, e se reúnem na sede da Comissão, em Washington.

As funções da Comissão são amplas, conforme se pode observar no art. 41 da Convenção Americana:

A Comissão tem a função principal de promover a observância e a defesa dos direitos humanos e, no exercício do seu mandato, tem as seguintes funções e atribuições:

a. estimular a consciência dos direitos humanos nos povos da América;

b. formular recomendações aos governos dos Estados membros, quando o considerar conveniente, no sentido de que adotem medidas progressivas em prol dos direitos humanos no âmbito de suas leis internas e seus preceitos constitucionais, bem como disposições apropriadas para promover o devido respeito a esses direitos

c. preparar os estudos ou relatórios que considerar convenientes para o desempenho de suas funções;

d. solicitar aos governos dos Estados membros que lhe proporcionem informações sobre as medidas que adotarem em matéria de direitos humanos; e. atender às consultas que, por meio da Secretaria-Geral da Organização dos Estados Americanos, lhe formularem os Estados membros sobre questões relacionadas com os direitos humanos e, dentro de suas possibilidades, prestarlhes o assessoramento que eles lhe solicitarem;

f. atuar com respeito às petições e outras comunicações, no exercício de sua autoridade, de conformidade com o disposto nos artigos 44 a 51 desta Convenção;

g. apresentar um relatório anual à Assembleia Geral da Organização dos Estados Americanos.

Além da Carta da OEA, com seus Protocolos, e da Convenção Americana sobre Direitos Humanos, a Comissão Interamericana possui também estatuto e 
regulamento próprios. São estes instrumentos básicos que disciplinam o funcionamento da instituição e o procedimento adotado quando ocorre uma denúncia de violação.

Uma das características mais importantes da Comissão Interamericana é a possibilidade de postulação atribuída a qualquer pessoa, grupo de pessoas ou entidade não governamental. $\mathrm{O}$ fato de permitir que os indivíduos encaminhem suas próprias denúncias torna o Sistema menos dependente de considerações políticas.

Frise-se que os Estados também podem apresentar denúncias contra outros países membros.

A admissibilidade da denúncia pela Comissão está condicionada a certos requisitos. Um dos requisitos principais é o prévio esgotamento dos recursos internos. De acordo com esse preceito, um Estado não pode ser acionado perante a jurisdição internacional sem que lhe seja permitido resolver a questão internamente. Tal aspecto ressalta a natureza complementar da jurisdição internacional, que não pretende substituir a jurisdição interna, mas apenas oferecer uma instância que assegure a efetivação dos direitos humanos quando o Estado fica impossibilitado de fazê-lo.

Contudo, podem ocorrer exceções ao esgotamento, como demora injustificada ou ineficácia do recurso, podendo então a questão ser levada diretamente ao foro internacional.

Alberto Santos ${ }^{10}$ ressalta que o requisito do esgotamento dos recursos internos tem sofrido relativizações. O autor, citando Cançado Trindade, afirma que, visando evitar o simples arquivamento das petições sem a apuração dos fatos, "a Comissão tem usado solicitar informações adicionais, adiar a decisão, com base na regra de interpretação que fora adotada na II Conferência Interamericana Extraordinária, de 1965, a qual dispôs que a exigência do prévio esgotamento dos recursos de direito interno não seria exigível nos 'casos gerais', reputados aqueles de violações gerais de direitos humanos"11.

Outro requisito relevante para a admissibilidade é a ausência de litispendência internacional. Ou seja, um mesmo caso não pode ser levado simultaneamente a dois Sistemas de Proteção, por exemplo, Sistema Interamericano e Sistema Global, devendose optar por um dos mecanismos.

\footnotetext{
${ }^{10}$ SANTOS, Alberto Silva. A internacionalização dos Direitos Humanos e o Sistema Interamericano de Proteção. Belo Horizonte: Arraes editores, 2012.p 113.

${ }^{11}$ Ibidem. p. 113.
} 
Superada a fase de análise da admissibilidade com sucesso, passa a ser observado o procedimento do art. 48 da Convenção, que prevê a realização de visitas em loco e abertura para soluções amistosas.

Alberto Santos $^{12}$ esclarecendo os procedimentos adotados após a admissibilidade da petição, afirma:

\begin{abstract}
A Comissão tem uma função preventiva e conciliatória, com procedimentos disciplinados do art. 49 a 51 da Convenção, o que acaba por constituir uma etapa de acesso à Jurisdição da Corte Interamericana, dada a condição estabelecida para esta, que deve somente analisar o caso na hipótese de ter sido previamente submetido à Comissão. Deste modo, na fase Conciliatória haverá um sistema de produção de relatórios pela Comissão, em caso de conciliação; em caso de insucesso, a Comissão redigirá um relatório, que poderá conter proposições e recomendações aos Estados interessados, os quais poderão se adequar a ele, sob pena do assunto ser submetido à Corte Interamericana, caso o Estado interessado tenha aceitado a jurisdição da Corte, nos termos do art. 51 da Convenção, o qual confere três meses ao Estado interessado para que tome providências cabíveis, caso não tenham sido atendidas as recomendações, a Comissão confere novo prazo ao Estado para tanto e, ao final, decidirá a Comissão, por maioria absoluta de voto de seus membros, se as medidas foram devidamente implementadas pelo Estado.
\end{abstract}

Por fim, nota-se que o Regulamento da Comissão, no art. 25, institui a competência para emitir medidas cautelares "em situações de gravidade e urgência a Comissão poderá, por iniciativa própria ou a pedido da parte, solicitar que um Estado adote medidas cautelares para prevenir danos irreparáveis às pessoas ou ao objeto do processo relativo a uma petição ou caso pendente" ${ }^{13}$. O citado dispositivo do Regulamento ressalta, ainda, que "estas medidas poderão ser de natureza coletiva a fim de prevenir um dano irreparável às pessoas em virtude do seu vínculo com uma organização, grupo ou comunidade de pessoas determinadas ou determináveis" ${ }^{14}$.

Há também previsão de outras medidas cautelares, como a do art. 76, o qual afirma que em caráter de urgência, “[...] num assunto ainda não submetido à consideração da Corte, a Comissão poderá solicitar àquela que adote medidas provisórias" ${ }^{15}$. Adiante trataremos sobre essa espécie cautelar, considerando sua utilização no caso Urso Branco.

\title{
2.4 A Corte Interamericana de Direitos Humanos
}

\footnotetext{
12 Ibidem. p. 115.

${ }^{13}$ Regulamento da Comissão Interamericana de Direitos Humanos art. 25.

${ }^{14}$ Regulamento da Comissão Interamericana de Direitos, art. 25.

${ }^{15}$ Regulamento da Comissão Interamericana de Direitos, art. 76.
} 
A Corte Interamericana de Direitos Humanos, segundo órgão da Convenção, é uma instituição judicial autônoma, não sendo órgão da OEA, mas sim da Convenção Americana de Direitos Humanos ${ }^{16}$. Esta Corte é composta por sete juízes nacionais de Estados membros da OEA, eleitos a título pessoal dentre juristas da mais alta autoridade moral, de reconhecida competência em matéria de direitos humanos, que reúnam as condições requeridas para o exercício das mais elevadas funções judiciais, de acordo com a lei do Estado do qual sejam nacionais, ou do Estado que os propuser como candidatos. Por regra do art. 52 da Convenção, não deve haver dois juízes da mesma nacionalidade ${ }^{17}$.

A Corte possui competência consultiva e contenciosa, nas palavras de Héctor Fix-Zamudio (apud Piovesan) ${ }^{18}$ :

\begin{abstract}
De acordo com o disposto nos arts. $1^{\circ}$ e $2^{\circ}$ de seu Estatuto, a Corte Interamericana possui duas atribuições essenciais: a primeira, de natureza consultiva, relativa à interpretação das disposições da Convenção Americana, assim como das disposições de tratados concernentes à proteção dos direitos humanos nos Estados Americanos; a segunda, de caráter jurisdicional, referente à solução de controvérsias que se apresentem acerca da interpretação ou aplicação da própria Convenção.
\end{abstract}

Sobre a função consultiva, qualquer membro da OEA - parte ou não da Convenção - pode solicitar o parecer da Corte em relação à interpretação da Convenção ou de qualquer outro tratado relativo à proteção dos direitos humanos nos Estados americano $^{19}$.

Em relação à função jurisdicional, a Convenção ${ }^{20}$ afirma que somente os Estados Partes e a Comissão têm direito de submeter caso à decisão da Corte. Frise-se que o reconhecimento da jurisdição contenciosa da Corte não é obrigatório. Sendo assim, o Estado pode ratificar a Convenção Americana e não reconhecer a jurisdição da Corte, a qual constitui cláusula facultativa da Convenção ${ }^{21}$. A declaração pode ser feita

\footnotetext{
${ }^{16}$ RAMOS, André de Carvalho. Curso de Direitos Humanos. São Paulo: Saraiva, 2014. p. 310.

${ }^{17}$ Convenção Interamericana De Direitos Humanos.

${ }^{18}$ PIOVESAN, Flávia. Direitos Humanos e o Direito Constitucional Internacional. 14. ed., rev. e atual. São Paulo: Saraiva, 2013. p. 213.

${ }^{19}$ PIOVESAN, Flávia. Direitos Humanos e o Direito Constitucional Internacional. 14. ed., rev. e atual. São Paulo: Saraiva, 2013. p.212.

${ }^{20}$ Convenção Interamericana de Direitos Humanos Art. 61

${ }^{21}$ RAMOS, André de Carvalho. Curso de Direitos Humanos. São Paulo: Saraiva, 2014. p. 311.
} 
incondicionalmente, ou sob condição de reciprocidade, por prazo determinado ou para casos específicos ${ }^{22}$.

É importante ressaltar que, como parte do Sistema Interamericano, a Corte possui função complementar em relação à jurisdição Estatal, nesse sentido, Cançado Trindade (apud Piovesan) ${ }^{23}$ afirma:

Os Tribunais internacionais de direitos humanos existentes - as Cortes Europeia e Interamericana de Direitos Humanos - não 'substituem' os Tribunais internos, e tampouco operam como tribunais de recursos ou de cassação de decisões dos Tribunais internos. Não obstante, os atos internos dos Estados podem vir a ser objeto de exame por parte dos órgãos de supervisão internacionais, quando se trata de verificar a sua conformidade com as obrigações internacionais dos Estados em matéria de direitos humanos.

O caráter subsidiário e complementar da Corte é enfatizado, ainda, pelo fato de que o acesso a este órgão se dá nos termos do art. 60 da Convenção Interamericana, o qual preleciona os mesmos requisitos necessários para acessar a Comissão, dentre os quais se destaca o esgotamento dos recursos internos.

Os Estados, ao reconhecerem a jurisdição da Corte, obrigatoriamente se comprometem a aceitar toda e qualquer decisão dela, relativa à interpretação e aplicação da Convenção Americana de Direitos Humanos, como obrigatória e de pleno direito.

O Brasil, apesar de ter ratificado e incorporado internamente a Convenção Americana de Direitos Humanos em 1992, somente em 1998 reconheceu a jurisdição contenciosa obrigatória da Corte Interamericana de Direitos Humanos.

Os sujeitos processuais que atuam perante o Tribunal são a Comissão Interamericana de Direitos Humanos, os Estados e, desde Regulamento da Corte, adotado sob a Presidência de Antonio Augusto Cançado Trindade, em novembro de 2000, os indivíduos peticionários em todas as etapas do procedimento perante a Corte $^{24}$.

Como citado, somente a Comissão e os Estados Partes podem submeter casos à Corte, constituídos, desse modo, como legitimados ativos. Cabe ressaltar que apesar do reconhecimento do indivíduo como sujeito de direito em todas as etapas do processo em trâmite perante a Corte, este não pode submeter seu caso diretamente ao referido Tribunal.

\footnotetext{
22 Convenção Interamericana de Direitos Humanos art. 62.

${ }^{23}$ PIOVESAN, Flávia. Direitos Humanos e o Direito Constitucional Internacional. 14. ed., rev. e atual. São Paulo: Saraiva, 2013.p.214.

${ }^{24}$ MIRANDA, Mariana Almeida Picanço de; CUNHA, José Ricardo. Poder Judiciário Brasileiro e Proteção Dos Direitos Humanos: Aplicabilidade e incorporação das decisões da Corte Interamericana de Direitos Humanos. Rio de Janeiro: Escola de Direito do Rio de Janeiro da Fundação Getúlio Vargas, Centro de Justiça e Sociedade, 2010. p. 32.
} 
No que tange à legitimidade passiva, $\operatorname{Ramos}^{25}$ afirma que esta "é sempre do Estado: a Corte IDH não é um Tribunal que julga pessoas. A Corte julga, assim, uma ação de responsabilidade internacional do Estado por violação de direitos humanos”.

\title{
2.4.1 Medidas provisórias
}

Segundo o artigo 63(2) da Convenção, em casos de extrema gravidade e urgência, e quando se fizer necessário evitar danos irreparáveis às pessoas, a Corte Interamericana, nos assuntos de que estiver conhecendo, poderá tomar as medidas provisórias que considerar pertinentes. Tal concessão poderá se dar de ofício ou mediante requerimento da vítima, suposta vítima ou de seu representante ${ }^{26}$. Se se tratar de assuntos que ainda não estiverem submetidos ao conhecimento da Corte, esta poderá atuar a pedido da Comissão.

Fernando G. Jayme (apud $\operatorname{Santos}^{27}$ ) afirma que as medidas provisórias são regidas pelo princípio da efetividade:

\begin{abstract}
(...) devem ser compreendidas 'por sua própria razão de ser, como verdadeiras garantias jurisdicionais de caráter preventivo'. Elas representam garantias no sentido de 'proteger, assegurar ou fazer valer a titularidade ou o exercício de um direito'. O fim visado pelas medidas provisórias permite que a Corte emita determinações total ou parcialmente distintas daquelas requeridas. A jurisprudência da Corte definitivamente estabeleceu o caráter tutelar, mais do que puramente cautelar, das medidas provisórias de proteção no universo conceitual do Direito Internacional dos Direitos Humanos.
\end{abstract}

As medidas provisórias também se prestam à proteção de uma coletividade de pessoas, contanto que esses indivíduos, ainda que inominados, sejam ao menos identificáveis e determináveis.

Percebemos que a Corte tem emitido diversas medidas provisórias em relação a coletividades no Brasil, em especial na ceara prisional, com emissão de medidas nos Casos Urso Branco (Rondônia), Complexo Penitenciário de Pedrinhas (Maranhão), Complexo Penitenciário do Curado (Pernambuco) e Penitenciária "Dr. Sebastião Martins Silveira" (São Paulo).

\footnotetext{
${ }^{25}$ RAMOS, André de Carvalho. Curso de Direitos Humanos. São Paulo: Saraiva, 2014. p. 312.

${ }^{26}$ SANTOS, Alberto Silva. A internacionalização dos Direitos Humanos e o Sistema Interamericano de Proteção. Belo Horizonte: Arraes editores, 2012. p. 124.

${ }^{27}$ SANTOS, Alberto Silva. A internacionalização dos Direitos Humanos e o Sistema Interamericano de Proteção. Belo Horizonte: Arraes editores, 2012. p 124.
} 
André Carvalho $\operatorname{Ramos}^{28}$ destaca que, diante da emissão de medidas provisórias, o Estado deve cumprir o quanto determinado e informar periodicamente a Corte Interamericana sobre a implementação das determinações. A Corte incluirá em seu relatório anual à Assembleia Geral uma relação das medidas provisórias que tenha ordenado durante o período do relatório e quando tais medidas não tenham sido devidamente executadas.

\section{O CASO URSO BRANCO: "A INSTITUCIONALIZAÇÃO DA BARBÁRIE"}

É oportuno salientar que a Casa de Detenção José Mário Alves, conhecida como Urso Branco, foi construída no final da década de 1990 com a função de abrigar presos provisórios para posterior encaminhamento a uma penitenciária. Entretanto, desde a sua construção, o estado passou a utilizar a casa de detenção como penitenciária, abrigando, em conjunto, presos condenados e presos provisórios.

O caso do Presídio Urso Branco trata do problema do massacre institucionalizado que colocou em grave risco a vida e a integridade dos internos da referida Penitenciária, por conta da superlotação, desde uma realocação geral do estabelecimento, realizada em 01 de janeiro de 2002, em que os internos que poderiam pôr em perigo a vida e a integridade de outros, foram transferidos a umas celas localizadas fora dos pavilhões gerais; os aproximadamente sessenta internos que se encontravam isolados em celas de "segurança" foram transferidos para as celas da população geral, colocando cinco em cada cela.

Aproximadamente às nove horas da noite desse mesmo dia, foi iniciado um "homicídio sistemático" dos internos que provinham das celas de "segurança".

Esses internos "gritaram pedindo ajuda aos agentes penitenciários, os quais não intervieram para evitar essas mortes" 29 .

No dia seguinte, 02 de janeiro de 2002, um "grupo de choque" da polícia de Rondônia entrou na penitenciária. O relatório da pessoa encarregada desta operação salientava que haviam sido encontrados 45 corpos de internos, "alguns deles decapitados, com os braços e as pernas mutilados pelo uso de armas cortantes. Outros teriam morrido em consequência de golpes desferidos com 'chunchos' (armas cortantes penetrantes

\footnotetext{
${ }^{28}$ RAMOS, André de Carvalho. Curso de Direitos Humanos. São Paulo: Saraiva, 2014.p. 314.

${ }^{29}$ COMISSÃO INTERAMERICANA DE DIREITOS HUMANOS. Relatório de Admissibilidade do Caso Urso Branco na Comissão Interamericana de Direitos Humanos.
} 
fabricadas pelos reféns presos)". O Governo do Estado de Rondônia emitiu um comunicado à imprensa no qual indicou que haviam falecido 27 pessoas.

As mortes continuaram. Logo depois, em 18 de fevereiro de 2002, foram encontrados os corpos de três internos em um túnel debaixo de uma cela. Dois dias mais tarde houve uma tentativa de homicídio de três internos de "segurança" que se encontravam nas celas improvisadas. No dia 8 de março de 2002 "houve novas tentativas de homicídio no interior da penitenciária”, e na madrugada do dia seguinte os reclusos destruíram 11 celas.

Estes acontecimentos motivaram a intervenção da Companhia de Controle de Distúrbios, a qual assegurou haver assumido o controle da Penitenciária Urso Branco. Entretanto, em 10 de março de 2002 ocorreram os homicídios de mais dois reclusos, cometidos por outros internos, "em um pátio, na presença dos demais internos, e sem que as forças especiais os impedissem".

Em 05 de março de 2002, a Justiça Global e a Comissão Justiça e Paz da Arquidiocese Porto Velho apresentaram à Comissão Interamericana de Direitos Humanos uma petição contra a República Federativa do Brasil. Esta petição denuncia a institucionalização da barbárie pelo Estado Brasileiro, já que o Estado não agiu positivamente para frear as mortes sistemáticas que ocorriam na unidade prisional Urso Branco.

No decorrer do relatório apresentado pelos peticionários é possível vislumbrar a situação de extrema violência e perigo em que se encontravam as pessoas privadas de liberdade na penitenciária, com a narração de homicídios e torturas perpetradas sem que o Estado interviesse.

Em 14 de março de 2002 a Comissão solicitou ao Estado a adoção de medidas cautelares com o objetivo de proteger a vida e a integridade pessoal dos internos da Penitenciária Urso Branco. Porém, em menos de dois meses após a solicitação da Comissão, cinco internos foram brutalmente assassinados. O Estado brasileiro alega que não há evidência de que agentes estatais tenham participado das mortes ocorridas no presídio, sendo estas uma ação dos próprios presos.

Em virtude da extrema gravidade e urgência do caso e a fim de evitar dano irreparável às vítimas, a Comissão Interamericana encaminhou um pedido de medidas provisórias junto à Corte no caso Urso Branco em 06 de junho de 2002.

Houve a continuidade das lesões, mesmo com a emissão das medidas provisórias, tanto que, em 2008, o ex-procurador-geral da República Antônio Fernando 
Souza protocolou no STF um pedido de intervenção federal em Rondônia, devido à crise de segurança no Presídio Urso Branco, em Porto Velho. Há seis anos, a ação tramita no STF e ainda não foi julgada.

\section{A ATUAÇÃO DO SIPDH NO CASO URSO BRANCO}

Como foi dito anteriormente, em 05 de março de 2002, o caso Urso Branco foi apresentado à Comissão Interamericana, por meio de petição elaborada pela Justiça Global e pela Comissão Justiça e Paz da Arquidiocese Porto Velho. Os peticionários requisitaram que a Comissão solicitasse ao governo brasileiro a adoção de medidas cautelares para proteger a vida e a integridade física das pessoas privadas de liberdade no Presídio "Urso Branco".

Em 14 de março de 2002, a Comissão enviou um pedido de medidas cautelares ao Estado brasileiro. Contudo, em 17 de abril de 2002 a CIDH foi informada sobre a ocorrência da execução de mais três presos nas dependências do presídio. Constatando a inadequação das medidas adotadas pelo Estado Brasileiro para cessar as violações contra os internos do Presídio Urso Branco, em cinco de junho de 2002 a CIDH solicitou medidas provisórias à Corte Interamericana de Direitos Humanos. Em 18 de junho de 2002 a Corte adotou as medidas provisórias.

Em cinco de junho de 2002, a requerimento dos peticionários, a Comissão abriu o caso, em conformidade com seu Regulamento.

A Corte Interamericana emitiu dez medidas provisórias entre o período de 18 de junho de 2002 e 25 de agosto de 2011, quando houve a cessação de tais medidas e o caso foi "arquivado" no âmbito da Corte.

A seguir nos deteremos na análise das medidas expedidas pela Corte no período supracitado, a fim de distribuir as determinações em eixos temáticos de violações e pontuar as colocações importantes feitas nos relatórios.

Conforme relatado acima, a primeira medida provisória expedida pela Corte Interamericana ocorreu em 18 de junho de 2002. Essa medida se destinou, precipuamente, a cessar as mortes que vinham ocorrendo no presídio desde o episódio de janeiro de 2002.

Desse modo, a Corte requisitou que o Estado adotasse "todas as medidas que sejam necessárias para proteger a vida e integridade pessoal de todas as pessoas recluídas na Penitenciária Urso Branco, sendo uma delas a apreensão das armas que se encontram 
em poder dos internos" ${ }^{30}$. Ainda foi requisitada a investigação sobre os homicídios ocorridos dentro do presídio bem assim a identificação e responsabilização dos culpados.

No segundo relatório, datado de 29 de agosto de 2002, ainda há urgência em cessar a ocorrência de mortes no presídio. A Corte afirma que o Estado tem a obrigação de adotar medidas de segurança para proteger as pessoas que estejam sujeitas a sua jurisdição, ressaltando que este dever é mais evidente ao se tratar de pessoas recluídas em um centro de detenção estadual, caso em que o Estado é o garante dos direitos das pessoas que se encontram sob sua custódia ${ }^{31}$.

Nessa resolução, a Corte também afirma a necessidade de separar os reclusos, de modo que deverão ser colocados em diferentes seções dentro do estabelecimento, segundo os motivos de sua detenção e o tratamento que corresponda aplicar-lhes. Ademais, os detentos em prisão provisória deveriam ser separados dos condenados.

Ressalta ainda a necessidade de coibir a violência perpetrada pelos funcionários da penitenciária, os quais deveriam, em suas relações com os reclusos, recorrer à força só em caso de legítima defesa, em tentativa de evasão ou de resistência pela força ou por inércia física a uma ordem baseada na lei ou nos regulamentos, sendo vedada a aplicação de castigos corporais, fechamento em cela escura bem assim toda sanção cruel, desumana ou degradante.

A Corte, ainda na resolução de 29 de Agosto de 2002, ressalta a necessidade de investigar os culpados por eventos ocorridos após a determinação da primeira resolução, tais como a manutenção de 308 internos durante quatro dias ininterruptos na quadra da penitenciária, nus, sem receber comida, recebendo água esporadicamente, fazendo suas necessidades fisiológicas nesse pátio e sofrendo agressões físicas.

Outro ponto importante desta resolução foi a solicitação de que o Estado e Comissão Interamericana de Direitos Humanos deveriam tomar as providências necessárias para a criação de um mecanismo apropriado para coordenar e supervisionar o cumprimento das medidas provisórias ordenadas pela Corte, de maneira a garantir livremente a comunicação entre os reclusos e as autoridades e organizações encarregadas

\footnotetext{
${ }^{30}$ CORTE INTERAMERICANA DE DIREITOS HUMANOS. Resolução de 18 de Junho de 2002, Medidas Provisórias Solicitadas Pela Comissão Interamericana De Direitos Humanos A Respeito Da República Federativa Do Brasil Caso Da Penitenciária Urso Branco.

31 CORTE INTERAMERICANA DE DIREITOS HUMANOS. Resolução de 29 de Agosto de 2002. Medidas Provisórias Solicitadas Pela Comissão Interamericana De Direitos Humanos A Respeito Da República Federativa Do Brasil Caso Da Penitenciária Urso Branco.
} 
de verificar o cumprimento das medidas e não tomar represália alguma em prejuízo dos reclusos que ofereçam informação a respeito.

Outra resolução, emitida em 22 de abril de 2004, ressalta a necessidade de investigar as violências cometidas dentro do presídio bem assim adequar as condições da penitenciária às normas internacionais de proteção dos Direito Humanos aplicáveis à matéria. Tais termos são reiterados pela resolução de 21 de setembro de 2005.

A sexta resolução, emitida em 02 de maio de 2008, traz posicionamentos relevantes da Corte, destacando que, embora o Brasil seja um Estado Federativo e a Penitenciária Urso Branco esteja localizada em uma de suas unidades federativas, isto não libera o Estado do cumprimento de suas obrigações de proteção. A CIDH ainda registra que até aquele momento a vigência das resoluções não havia surtido efeito substancial, recomendando-se ao Governo a articulação em nível interno para proteger a vida e a integridade dos beneficiários, cogitando uma intervenção federal no Estado de Rondônia. ${ }^{32}$

A Corte reitera, ainda, a especial posição de proteção que o Estado deve assumir frente às pessoas detidas, tendo em vista a particular relação de sujeição existente entre o interno e o Estado. Nessa situação, o dever geral do Estado de respeitar e garantir os direitos adquire um matiz especial que obriga o Estado a oferecer aos internos, com o objetivo de proteger e garantir seu direito à vida e à integridade pessoal, as condições mínimas compatíveis com sua dignidade enquanto permanecem no cárcere ${ }^{33}$.

Nesta última resolução a Corte repete a necessidade de o Estado conduzir com seriedade as investigações sobre os fatos ocorridas na penitenciária, destacando que esta é uma medida fundamental para evitar a repetição das violações aos direitos humanos perpetradas no caso.

Através da resolução de 17 de agosto de 2009 foram convocados o Estado do Brasil, os representantes dos beneficiários e a Comissão Interamericana de Direitos Humanos a uma audiência pública que seria realizada na sede da Corte Interamericana de Direitos Humanos, em 30 de setembro de 2009.

\footnotetext{
${ }^{32}$ CORTE INTERAMERICANA DE DIREITOS HUMANOS. Resolução de 02 de maio de 2008. Medidas Provisórias Solicitadas Pela Comissão Interamericana De Direitos Humanos A Respeito Da República Federativa Do Brasil Caso Da Penitenciária Urso Branco.

${ }^{33}$ CORTE INTERAMERICANA DE DIREITOS HUMANOS. Resolução de 02 de maio de 2008. Medidas Provisórias Solicitadas Pela Comissão Interamericana De Direitos Humanos A Respeito Da República Federativa Do Brasil Caso Da Penitenciária Urso Branco.
} 
Na oitava resolução, datada de 25 de novembro de 2009, a Corte reconhece os esforços que o Estado brasileiro empreendeu com o fim de melhorar as condições de detenção no Presídio, entre o que se destacam a diminuição da superlotação e a melhora nas instalações físicas. Além disso, a Corte considera positivo que o próprio Estado tenha afirmado na audiência pública de 30 de setembro de 2009 que: a) o excesso de população em Urso Branco revela-se como o maior problema da unidade, do qual decorrem praticamente todos os demais; b) há problemas com o fornecimento de produtos de higiene pessoal e colchões; e c) é necessário adotar medidas a fim de melhorar a assistência social e os serviços de saúde dos beneficiários e a adequação das estruturas de algumas celas.

Assim, a Corte assevera que Estado deveria continuar adotando de forma imediata todas as medidas que fossem necessárias para proteger eficazmente a vida e a integridade de todas as pessoas privadas de liberdade na Penitenciária Urso Branco, bem como de todas as pessoas que nela ingressassem, entre elas os visitantes e os agentes de segurança que prestassem serviços na mesma.

Na penúltima resolução emitida no caso, em 26 de julho de 2011, ainda há várias alegações sobre as condições de vida degradantes e a carência estrutural da instituição. Nesse sentido, podem ser destacadas as colocações feitas pelos representantes dos beneficiários, que afirmam a insuficiência de agentes penitenciários, a superlotação, arbitrariedades cometidas por funcionários da penitenciária que agravam o clima de violência. Além disso, salientam a falta de atendimento médico adequado, de modo que os detentos com doenças tratáveis são forçados a viver com dor, a alimentação de péssima qualidade e o acesso aos produtos de higiene insuficiente para as necessidades básicas.

Ainda na resolução de 26 de julho de 2011 é convocada uma nova audiência pública com a presença dos representantes da República Federativa do Brasil, os representantes dos beneficiários e a Comissão Interamericana de Direitos Humanos em 25 de agosto de 2011, em Bogotá, na Colômbia.

Na última resolução, emitida em 25 de agosto de 2011, foi informado pelo Estado Brasileiro que determinadas autoridades federais e do Estado de Rondônia bem como representantes dos beneficiários firmaram em 24 de agosto de 2011 o "Pacto para melhoria do sistema prisional do estado de Rondônia e levantamento das medidas 
provisórias outorgadas pela Corte Interamericana de Direitos Humanos" 34 , no qual estão previstos eixos de atuação com vistas a adequar as condições da instituição aos padrões internacionais.

A Corte observou que desde dezembro de 2007 não houve o registro de mortes violentas ou motins na Penitenciária Urso Branco. Além disso, a população carcerária diminuiu para 700 internos em 2009 e desde então permaneceu sem maiores variações. O Estado se encontra, ainda, investigando as denúncias de violência e maustratos denunciados pelos representantes, inclusive alguns processos penais já foram sentenciados em primeira instância, tais como os relacionados com os eventos ocorridos em janeiro de 2002 que deram origem às presentes resoluções ${ }^{35}$.

Após analisar as medidas provisionais expedidas pela Corte Interamericana, podemos elencar alguns eixos que suscitaram maior preocupação do Tribunal: assassinatos sistemáticos, violência institucionalizada, superlotação, atendimento médico deficiente, número insuficiente de agentes penitenciários, infraestrutura precária, fornecimento insuficiente de alimento, água e remédios.

Dentre os eixos supracitados, adotaremos a temática da saúde na Penitenciária Urso Branco, a fim de exemplificar como o Estado se mobilizou para implementar este direito frente às medidas expedidas pela Corte bem assim os obstáculos enfrentados neste intento.

A escolha desse eixo temático se justifica pela ênfase atribuída à questão da saúde no relatório do mutirão carcerário realizado pelo CNJ em 2014, o que nos fornece informações para realizar as análises pertinentes.

\section{ATUAÇÃO BRASILEIRA FRENTE ÀS MEDIDAS PROVISIONAIS EXPEDIDAS PELA CORTE INTERAMERICANA}

\subsection{Atuação Geral}

\footnotetext{
34 CORTE INTERAMERICANA DE DIREITOS HUMANOS. Resolução de 25 de Agosto de 2011. Medidas Provisórias Solicitadas Pela Comissão Interamericana De Direitos Humanos A Respeito da República Federativa Do Brasil Caso Da Penitenciária Urso Branco.

35 CORTE INTERAMERICANA DE DIREITOS HUMANOS. Resolução de 25 de Agosto de 2011. Medidas Provisórias Solicitadas Pela Comissão Interamericana De Direitos Humanos A Respeito da República Federativa Do Brasil Caso Da Penitenciária Urso Branco.
} 
O Estado Brasileiro, diante das obrigações assumidas no Pacto de San José da Costa Rica e a aceitação da jurisdição da Corte Interamericana, tem o dever de acatar as decisões desse Tribunal.

Assim, cabe analisar as articulações internas empreendidas pelo Brasil a fim de atender às medidas provisionais emitidas pela Corte.

Num primeiro momento, é preciso ressaltar que não há nenhuma normatização específica sobre a maneira como as determinações expedidas pelo Sistema Interamericano de Proteção dos Direitos Humanos devem ser implementadas no âmbito doméstico, de modo que o atendimento a tais medidas ocorre eminentemente na esfera política.

Com o passar do tempo, criou-se uma conformação de atuação entre a Secretaria de Direitos Humanos, a Advocacia Geral da União e o Ministério das Relações Exteriores, mas tal conformação varia diante das circunstâncias do caso e se presta mais à defesa processual do que à implementação concreta das determinações da Corte.

O Ministério das Relações Exteriores (MRE) é um órgão político de auxílio ao Presidente da República, cujas áreas de competência abrangem atividades de política internacional e relações internacionais. Há uma divisão específica de Direitos Humanos do MRE que faz a interlocução das comunicações com o SIDH em todas as fases de um caso.

A Secretaria de Direitos Humanos, órgão com status de Ministério, é responsável pela implementação de políticas públicas que versem sobre matéria de direitos humanos. O MRE comunica a SDH sobre a existência de denúncia no âmbito do SIPDH, de modo que esta última contata as vítimas envolvidas no caso concreto.

A Advocacia-Geral da União é o órgão responsável pela representação judicial da União e consultoria e assessoramento jurídico do Poder Executivo. Possui um departamento internacional que auxilia a SDH e o MRE tanto na defesa brasileira quanto na implementação de medidas de recomendação e de condenação ${ }^{36}$.

VIEIRA $^{37}$ aponta que se o caso já avançou para o relatório com recomendações, é a SDH que organiza internamente o conteúdo da defesa do Estado: são

\footnotetext{
36 VIEIRA, Oscar Vilhena; et al. Implementação das recomendações e decisões do sistema interamericano de direitos humanos no Brasil : institucionalização e política. São Paulo: Direito GV, 2013. (Série pesquisa direito GV). p. 19.

37 VIEIRA, Oscar Vilhena; et al. Implementação das recomendações e decisões do sistema interamericano de direitos humanos no Brasil : institucionalização e política. São Paulo: Direito GV, 2013. (Série pesquisa direito GV). p. 19/20.
} 
feitas tentativas de contato com o ente federado no qual ocorreu a violação, com o objetivo de fomentar um processo de solução amistosa. Se o caso vai para a Corte Interamericana, o Itamaraty (órgão diplomático), a SDH e a AGU atuam de forma conjunta, como um núcleo de defesa, eventualmente com a participação de outros órgãos relevantes, a depender de cada caso.

Deve-se reiterar que a conformação acima exposta está direcionada precipuamente ao trâmite processual perante o Sistema Interamericano, não constituindo, assim, um mecanismo hábil à implementação das decisões no caso concreto.

A despeito da inexistência de uma normatização rígida sobre a efetivação das decisões da Corte Interamericana, vale ressaltar que o III Programa Nacional de Direitos Humanos trouxe um objetivo estratégico específico relacionado ao tema, sob o nome "Monitoramento dos compromissos internacionais assumidos pelo Estado brasileiro em matéria de Direitos Humanos". Nele se destacam as seguintes ações:

a) Elaborar relatório anual sobre a situação dos Direitos Humanos no Brasil, em diálogo participativo com a sociedade civil.

Responsáveis: Secretaria Especial dos Direitos Humanos da Presidência da República; Ministério das Relações Exteriores.

e) Definir e institucionalizar fluxo de informações, com responsáveis em cada órgão do Governo Federal referentes aos relatórios da Comissão Interamericana de Direitos Humanos e às decisões da Corte Interamericana de Direitos Humanos.

Responsáveis: Secretaria Especial dos Direitos Humanos da Presidência da República; Ministério das Relações Exteriores.

f) Criar banco de dados público sobre todas as recomendações dos sistemas ONU e OEA feitas ao Brasil, contendo as medidas adotadas pelos diversos órgãos públicos para seu cumprimento.

Responsáveis: Secretaria Especial dos Direitos Humanos da Presidência da República; Ministério das Relações Exteriores.

Nesse documento ficou consignada a disposição de institucionalizarem-se os procedimentos para implementação das medidas impostas ao país pelo Sistema 
Interamericano, consubstanciada em objetivos que devem ser perseguidos pelo governo brasileiro $^{38}$.

\subsection{Atuação do Governo Brasileiro no Caso Urso Branco}

No presente escopo, cabe ressaltar como o Governo brasileiro se mobilizou, em todas as esferas federativas, para executar as melhorias determinadas pela Corte no Caso Urso Branco.

Considerando a disposição do governo Federal em atender às medidas provisionais determinadas pela Corte e observando as competências constitucionais de colaborar com os governos estaduais no que for necessário para a promoção e defesa dos direitos humanos, a Secretaria de Direitos Humanos, por meio da Resolução no 17 de 02 de agosto de 2004, criou a Comissão Especial do Conselho de Defesa dos Direitos Humanos. Tal Comissão teria o objetivo de coordenar, supervisionar e monitorar a aplicação das medidas provisionais determinadas pela Corte Interamericana de Direitos Humanos, concernentes à Casa de Detenção José Mário Alves da Silva.

A Comissão foi composta por representantes da União Federal (Ministério da Justiça, Secretaria Especial de Direitos Humanos, Departamento Penitenciário Nacional, Conselho Nacional de Política Criminal e Penitenciária, Advocacia-Geral da União e Ministério das Relações Exteriores), representantes do Poder Executivo, do Poder Judiciário e do Ministério Público do Estado de Rondônia, além de representantes da sociedade civil (Centro de Justiça Global, Comissão de Justiça e Paz da Arquidiocese de Porto velho/RO e Ordem dos Advogados do Brasil/RO).

Segundo se pode extrair da leitura do documento que criou a Comissão, caberia a esta estabelecer livre canal de comunicação entre a Comissão Especial e os detentos, através do livre acesso de seus membros às dependências da unidade carcerária, o sigilo das correspondências entre os detentos e a Comissão e a realização de reuniões periódicas com os encarcerados. Além disso, a Comissão Especial seria responsável por encaminhar para exame de corpo de delito os detentos com suspeita de terem sido vítimas de agressão ou de prática de tortura.

\footnotetext{
38 VIEIRA, Oscar Vilhena; et al. Implementação das recomendações e decisões do sistema interamericano de direitos humanos no Brasil : institucionalização e política. São Paulo: Direito GV, 2013. (Série pesquisa direito GV). p. 18.
} 
Cabe salientar que, mesmo com o arquivamento do caso no âmbito da Corte Interamericana, a Comissão Especial mantém suas atividades de monitoramento da situação prisional, tendo-se notícia que em abril de 2015 fora realizada visita da Comissão Especial à Penitenciária Urso Branco ${ }^{39}$.

Com o impulso obtido através da visibilidade dada ao caso e pela criação da Comissão Especial "Urso Branco", outras ações estatais foram desenvolvidas com o intuito de monitorar a situação prisional brasileira. Nesse sentido, destaca-se o Mutirão Carcerário, realizado desde agosto de 2008, pelo Conselho Nacional de Justiça (CNJ), órgão máximo do Poder Judiciário.

Essa iniciativa reúne juízes que percorrem os estados para analisar a situação processual das pessoas que cumprem pena, além de inspecionar unidades carcerárias, com o objetivo de evitar irregularidades e garantir o cumprimento da Lei de Execuções Penais.

Embora o Mutirão carcerário não tenha sido criado com o propósito específico de atender às determinações da Corte, percebe-se que essa iniciativa também decorre da visibilidade que a precariedade do Sistema Penitenciário Brasileiro tomou no âmbito internacional.

No tópico seguinte será discutido o relatório elaborado pelo CNJ em relação às unidades prisionais do Estado de Rondônia, em especial, a Penitenciária "Urso Branco".

Por fim, cabe tratar sobre o "Pacto para melhoria do Sistema Prisional Do Estado De Rondônia e levantamento das medidas provisórias outorgadas pela Corte Interamericana De Direitos Humanos", assumido em agosto de 2011, com o fito de cessar a expedição das medidas provisionais, o que, de fato, ocorreu.

Esse Pacto foi firmado por diversos órgãos da União (Ministério da Justiça Departamento Penitenciário Nacional, Secretaria de Direitos Humanos da Presidência da República, Conselho de Defesa dos Direitos Humanos e Ministério das Relações Exteriores - Divisão de Direitos Humanos), pelo Governo do Estado de Rondônia, pelo Ministério Público e Defensoria Pública Estadual e, ainda, pelo Poder Judiciário do Estado de Rondônia. Além dos citados, houve a participação dos peticionários do Caso Urso Branco, a Comissão Justiça e Paz da Arquidiocese de Porto Velho e a Organização

\footnotetext{
${ }^{39}$ Portal do Governo do Estado de Rondônia. Comissão Especial da Corte Interamericana de Direitos Humanos avalia melhorias no presídio Urso Branco. 17 de Abril de 2015. Disponível em: $<$ http://www.rondonia.ro.gov.br/2015/04/54724/>. Acesso em: 20 de junho de 2015.
} 
Justiça Global, que se comprometeram a fiscalizar a execução das melhorias e não se opor ao levantamento das medidas provisórias.

O Pacto foi dividido em três etapas com medidas de curto, médio e longo prazo, com vistas a adequar as condições da Penitenciária Urso Branco e do sistema prisional do Estado de Rondônia em geral aos padrões de direitos humanos internacionais. Essas medidas se transvestiam em cinco metas, quais sejam: I- o investimento em infraestrutura; II- a contratação e formação de agentes penitenciários e servidores administrativos; III- a apuração dos acontecimentos e responsabilização dos culpados pelos fatos ocorridos no Presídio urso Branco; IV- aperfeiçoamento dos serviços, mobilização e inclusão social e, por fim, V-ações concretas para a criação e consolidação de mecanismos de combate e prevenção à violência, aos maus tratos e à tortura no sistema prisional.

Encerrando essa análise, deve-se enfatizar que o Brasil, na condição de Estado Federal, deve continuar a tomar as medidas pertinentes para mobilizar a ação das instituições e do Governo do Estado de Rondônia, a fim de que esses possam adotar as disposições cabíveis para o cumprimento das determinações proferidas pela Corte. Ademais, cabe lembrar que as obrigações convencionais assumidas pelo país vinculam todos os agentes, órgãos e entidades do Estado.

\section{RELATÓRIO CNJ ATUALIZAdo E A QUESTÃO DA SAÚdE NO "CASO URSO BRANCO"}

O relatório do Conselho Nacional de Justiça elaborado no Mutirão Carcerário de 2014 expõe que a Casa de Detenção José Mário Alves da Silva foi palco de um dos mais sangrentos massacres da história prisional brasileira, contabilizando mais de 100 mortes violentas entre os anos de 2000 e 2007.

O Mutirão Carcerário regional de Rondônia/Urso Branco teve início no dia 17 de fevereiro de 2014 e foi concluído em 21 de fevereiro de 2014 com as metas de analisar a situação jurídico-processual dos presos e suas condições de vida no estabelecimento. Participaram do Mutirão magistrados, servidores e estagiários. Durante a visita foi analisada a situação jurídica-processual dos 653 presos recolhidos na unidade.

Já a inspeção da penitenciária foi conduzida por magistrados, Promotores De Justiça, Defensores Públicos e um Procurador Da República. Na data da inspeção, 19 de 
fevereiro de 2014, o Presídio se encontrava com 672 internos, representando uma lotação de $47,36 \%$ acima do número de vagas.

$\mathrm{Na}$ inspeção, constatou-se que não é disponibilizada atividade educativa no Presídio Urso Branco e a atividade laboral é ínfima (20 vagas para a manutenção da unidade e entrega da alimentação para os outros presos).

Mesmo diante das Medidas Provisionais expedidas pela Corte, ainda existe um baixo contingente de agentes penitenciários, $16 \mathrm{em}$ cada turno, o que, segundo o Diretor da Instituição, coloca em risco a segurança no presídio.

Um dado que chama atenção no relatório elaborado pelo CNJ é a precariedade da questão da saúde no presídio. Nesse sentido, são elucidados dados trazidos pelo relatório enviado pelo Conselho da Comunidade de Porto Velho, resultante da inspeção ocorrida no dia 13 de fevereiro de 2014. Tal documento aponta que apenas um médico clínico geral atenderia aproximadamente 15 presos três vezes por semana e, ainda, um psiquiatra atenderia uma vez por semana. Esse número de profissionais era insuficiente para receber a demanda gerada por um contingente de 673 presos que ocupavam o presídio no período.

Além disso, o documento elaborado pelo Conselho da Comunidade assinala que a Penitenciária Urso branco possui grande deficiência no que se refere à disponibilidade de medicamentos, os presos reclamaram que só haveria remédio para dor e que na ocorrência de uma enfermidade aguda havia muita demora em serem atendidos por um profissional de saúde, bem como não há transporte para conduzi-los para um posto de saúde ou hospital. A gravidade da situação é tal que um preso provisório, baleado, foi obrigado a fazer curativos com papel higiênico, conforme o relato do Conselho da Comunidade.

O relatório organizado pelo CNJ salienta que as condições de superlotação combinadas à infraestrutura precária e à falta de atendimento médico facilitam a propagação de doenças.

Assim, a saúde é tida, atualmente, como uma das vertentes mais precárias do Sistema Prisional do Estado de Rondônia. O relatório enfatiza que, diante do extremo da situação, a $7^{\text {a }}$ Promotoria de Proteção e Defesa da Saúde do Ministério Público Estadual, assinalando "que não poderia ficar inerte em face do descaso dos gestores na constante falte de medicamentos essenciais necessários e indispensáveis à comunidade prisional da Capital do Estado", ajuizou ação civil pública (0019279-29.2013.8.22.0001) para obrigar o Município de Porto Velho (Secretaria Municipal de Saúde) a suprir a saúde Prisional, 
expondo que é obrigação do município prestar saúde condigna e efetiva às pessoas reclusas.

Concluindo o relatório, a equipe do CNJ aponta que a Casa de Detenção José Mario Alves/Urso Branco não é mais palco de massacres, como o evento que desencadeou a expedição das Medidas Provisórias pela Corte Interamericana.

No entanto, as melhorias efetuadas na instituição ainda são insuficientes para assegurar padrão de vida digno aos presos. Nesse sentido, o relatório ${ }^{40}$ ressalta que:

[...] a exigência da Corte Interamericana de Direitos Humanos da OEA, de garantia dos direitos à vida, integridade e proteção dos presos sob custódia nessa unidade prisional não esta sendo cumprida. Presos estão adoecendo e morrendo, de forma silenciosa e anônima, pelo falta de atendimento médicohospitalar adequando e pela ausência de medicamento básico nas Unidades Prisionais. O Direito à saúde e a Vida é garantido a todos. E os apenados não devem ser colocados pelo Estado e Sociedade em uma escala discriminatória quanto ao merecimento destes direitos.

O direito à saúde faz parte do arcabouço de direitos sociais constitucionalmente previstos que devem ser assegurados à população indistintamente. Não há na Constituição Federal de 1988 ou em qualquer lei interna previsão que discrimine a população carcerária como subgrupo que deve ser privado de direitos básicos. Pelo contrário, o inciso XLIX do artigo $5^{\circ}$ da Constituição federal Brasileira afirma que é assegurado aos presos o respeito à integridade física e moral.

O direito à saúde foi alvo específico de análise pela Corte Interamericana durante a expedição das medidas provisórias, contudo, observamos que a realização deste direito ainda é uma utopia no Presídio Urso Branco.

Diante deste panorama, é oportuno avaliar o recorte sobre a efetivação do direito à saúde na Casa de Detenção José Mário Alves. Tal análise se presta a cumprir o objetivo deste trabalho, que é verificar como ocorre a implementação das medidas provisionais emitidas pela Corte Interamericana no Brasil, salientando os entraves e caminhos que se apresentam na consecução deste intuito.

\section{OS ENTRAVES À IMPLEMENTAÇÃO DAS MEDIDAS DA CORTE INTERAMERICANA NO BRASIL E O DIREITO À SAÚDE}

\footnotetext{
${ }^{40}$ CONSELHO NACIONAL DE JUSTIÇA. MUTIRÃO CARCERÁRIO REGIONAL NO PRESÍDIO URSO BRANCO - RONDÔNIA. 2014.P.26. Disponível em: < http://www.cnj.jus.br/images/programas/mutiraocarcerario/relatorios/Relatorio_Mutirao_RONDONIA_reduzido.pdf.>. Acesso em: 11 de abril de 2015.
} 
A Corte não especifica quais os mecanismos institucionais para o cumprimento das suas determinações pelo Estado brasileiro. Este fator aliado à falta de normatização interna sobre o modo de execução de tais determinações cria um ambiente de insegurança.

Normalmente o atendimento às determinações emitidas pela Corte se dá por meio de acordos e convênios de cooperação internos, os quais são vínculos frágeis que estão sujeitos às oscilações da conjuntura política brasileira para sua efetividade.

Nesse sentido, Coimbra ${ }^{41}$, analisando os desafios à implementação das Decisões da Corte no Brasil, afirma:

\begin{abstract}
A articulação por convênios ou acordos de cooperação, apesar da vantagem de permitir uma interação institucional sem a necessidade de reformas legislativas e/ou administrativas complexas, é baseada na vontade política do órgão de participar ou não, bem como de assumir ou não compromissos, que podem ser insuficientes para cumprir as determinações do SIDH. Para que uma decisão da Corte IDH seja cumprida, a associação de órgãos pode ser necessária, e não discricionária como é na atualidade da organização jurídica brasileira. Dessa forma, garantir tal associação é um desafio interno que dificulta inclusive a atribuição de responsabilidade de cada órgão, em caso de descumprimento das medidas previstas na sentença.
\end{abstract}

No caso específico do Presídio Urso Branco, foi firmado um acordo entre entes federativos e instituições, o "Pacto para melhoria do Sistema Prisional Do Estado De Rondônia e levantamento das medidas provisórias outorgadas pela Corte Interamericana De Direitos Humanos", assumido em agosto de 2011 pela União (Ministério da Justiça - Departamento Penitenciário Nacional, Secretaria de Direitos Humanos da Presidência da República, Conselho de Defesa dos Direitos Humanos e Ministério das Relações Exteriores - Divisão de Direitos Humanos), pelo Governo do Estado de Rondônia, pelo Ministério Público e Defensoria Pública Estadual e, ainda, pelo Poder Judiciário do Estado de Rondônia. Tal vínculo não surtiu os efeitos esperados e, ainda, cometeu o equívoco de não envolver a participação do Município de Porto Velho, o qual teria importante papel na execução de melhorias essenciais, como a ampliação do acesso das pessoas privadas de liberdade à atenção básica do Sistema único de Saúde, que é de competência municipal.

\footnotetext{
${ }^{41}$ COIMBRA, Elisa Mara. Sistema Interamericano de Direitos Humanos: Desafios à implementação das decisões da Corte no Brasil. SUR. Revista Internacional de Direitos Humanos / Sur - Rede Universitária de Direitos Humanos - São Paulo v.10, n.19, nov. 2013. p. 59.
} 


\title{
7.1 A Questão da Saúde No Presídio Urso Branco
}

Prover a atenção médica adequada às pessoas privadas de liberdade é uma obrigação que deriva diretamente do dever do Estado de garantir a integridade física destas. Esse aspecto foi ressaltado diversas vezes nas medidas provisionais emitidas pela Corte no Caso Urso Branco.

As pessoas privadas de liberdade se encontram numa posição de subordinação frente ao Estado, do qual passam a depender para a satisfação de suas necessidades. Nesse sentido, ao privar a liberdade de uma pessoa, o Estado adquire especial responsabilidade e se constitui em garantidor dos direitos fundamentais, em especial dos direitos à vida e à integridade pessoal, de onde se origina o dever estatal de salvaguardar a saúde dos reclusos, concedendo-lhes assistência médica adequada.

No "Informe sobre os Direitos Humanos das Pessoas Privadas de Liberdade nas Américas", elaborado pela Comissão interamericana, foram estabelecidos, sob a luz dos entendimentos do Sistema Interamericano, os parâmetros de atenção médica adequada no Sistema Penitenciário. Dentre estes, descrevemos o seguinte posicionamento $^{42}$ :

\begin{abstract}
As pessoas privadas de liberdade têm direito à saúde, entendida como o desfrute do mais alto nível possível de bem estar físico, mental e social, que inclui, entre outros, a atenção médica, psiquiátrica e odontológica adequada; a disponibilidade permanente de profissional médico idôneo e imparcial; o acesso a tratamentos e medicamentos apropriados e gratuitos; a implementação de programas de educação e promoção em saúde, imunização, prevenção e tratamento de enfermidades infecciosas, endêmicas e de outra índole; e as medidas especiais para as necessidades particulares de saúde das pessoas privadas de liberdade pertencentes a grupos vulneráveis ou de alto risco, tais como: idosos, as mulheres, crianças, pessoas com incapacidades, as pessoas portadoras de HIV/AIDS, tuberculose, e as pessoas com enfermidades em fase terminal.
\end{abstract}

O conceito exposto é muito amplo, mas permite extrair a imprescindibilidade da efetivação do direito à saúde no sistema prisional, considerado como pressuposto de conservação da integridade física do indivíduo.

Nesse sentido, passaremos a expor alguns dos entraves à consolidação deste direito bem assim ao acatamento às determinações da Corte Interamericana.

\footnotetext{
${ }^{42}$ COMISSÃO INTERAMERICANA DE DIREITOS HUMANOS. Informe sobre os Direitos Humanos Das Pessoas Privadas de liberdade nas Américas. 2011. p. 199/200.
} 
No Brasil, a Constituição Federal, em seu art. 196, estabelece que "a saúde é direito de todos e dever do Estado, garantido mediante políticas sociais e econômicas que visem à redução do risco de doença e de outros agravos e ao acesso universal e igualitário às ações e serviços para sua promoção, proteção e recuperação". Nesse contexto, foi regulamentado pela Lei 8.080/90 o Sistema Único de Saúde (SUS), o qual tem a gestão marcada pela descentralização, com direção única em cada esfera de governo. Isso quer dizer que todos os entes federativos têm a obrigação de garantir e promover a saúde.

A Lei Orgânica da Saúde (Lei 8.080/90), ao regulamentar os princípios constitucionais do setor, atribuiu à esfera municipal a responsabilidade de gestão e gerência dos serviços de assistência individual e coletiva. O município passou a ser a base do sistema, cabendo a ele a formulação das políticas aplicáveis em seu âmbito, assim como o planejamento, o controle e a avaliação das ações e serviços públicos e privados estabelecidos em sua esfera de atuação ${ }^{43}$.

No âmbito do Sistema Prisional, foi criado o Plano de Saúde Nacional do Sistema Penitenciário (Portaria Interministerial 1777/2003). Tal plano prevê a inclusão da população penitenciária no SUS. Em 2014, complementando este plano, foi criada pelos os Ministros de Estado da Saúde e da Justiça a Portaria Interministerial nº01/2014, que institui a "Política Nacional de Atenção Integral à Saúde das Pessoas Privadas de Liberdade no Sistema Prisional (PNAISP) no âmbito do Sistema Único de Saúde (SUS)". Segundo o art. 17, inciso I, da citada Portaria, cabe ao município executar, no âmbito da atenção básica, as ações de promoção, proteção e recuperação da saúde da população privada de liberdade referenciada em sua pactuação.

Diante destas considerações, passamos a compreender a complexidade da efetivação do direito à saúde nas penitenciárias. Tornar o direito à saúde uma realidade não se restringe a uma mera decisão política da União. O Brasil é uma federação e a competência de execução pertence a todos os níveis federativos, com ênfase na importâcia concedida ao Município na execução destas políticas, segundo a normatização interna.

Nesse momento, percebemos a dificuldade que uma decisão internacional tomada no âmbito da Corte Interamericana encontra para se efetivar na esfera regional, especialmente em Estados Federativos como o Brasil, em que a implementação das

\footnotetext{
${ }^{43}$ ORTIGA, Ângela Maria Blatt; CONILL, Leonor Minho. Municipalização Da Saúde: A Trajetória No Estado De Santa Catarina. Revista de Saúde Pública de Santa Catarina. Florianópolis v. 1, n. 1, jan./jul. 200927.27 D. 27 em: $<$ http://esp.saude.sc.gov.br/sistemas/revista/index.php/inicio/article/viewFile/5/74>. Acesso em: 26 de junho de 2015.
} 
decisões depende dos Estados da União e dos Municípios, os quais são pouco afeitos às questões de Direito Internacional.

Nesse sentido, percebemos que a efetivação do direito à saúde, na conjuntura brasileira, depende em grande parte da vontade política dos gestores municipais, os quais não são incluídos nos acordos e convênios firmados pela União.

No Caso Urso Branco, apreendemos o quanto o alcance de níveis dignos de atenção em saúde se encontra distante. Como foi ressaltado anteriormente, a gestão do município de Porto Velho não firmou o "Pacto para melhoria do Sistema Prisional" de 2011, o que pode ter comprometido a obtenção de atendimento em saúde pela população carcerária.

De todo modo, resta consignado que, até o momento, as pessoas encarceradas no Presídio urso Branco não possuem efetivo acesso à saúde. Essa afirmação pode ser comprovada pelas denúncias que várias organizações da sociedade civil têm empreendido contra as péssimas condições de vida da penitenciária.

Nesse sentido, há denúncia feita pelo Sindicato dos Agentes Penitenciários e Socioeducadores do Estado de Rondônia (Singeperon) ${ }^{44}$, em 24 de março de 2015, ao Tribunal de Justiça de Rondônia e ao Ministério Público. A Organização afirma que o governo está descumprindo continuamente o "Pacto internacional para Melhoria do Sistema Prisional do Estado de Rondônia e Levantamento das Medidas Provisórias Outorgadas pela Corte Interamericana", o que pode ser aferido pelo agravamento das condições de vida e superlotação no Sistema Prisional do estado de Rondônia.

Além disso, a questão da saúde no Sistema Prisional tem sido exposta em diversas Medidas Provisionais expedidas pela Corte em relação ao Brasil. Destacam-se os casos do Complexo Penitenciário de Pedrinhas (localizada no Maranhão), Complexo Penitenciário do Curado (localizada em Pernambuco) e da Penitenciária "Dr. Sebastião Martins Silveira" (localizada em São Paulo). Nos três casos houve a discussão em torno do acesso à saúde pela população prisional.

\footnotetext{
44 SINGEPEREON. Estado continua descumprindo Pacto internacional de melhoria do sistema prisional, denuncia Singeperon. Disponível em: $<$ http://www.singeperon.com.br/portal/index.php?option=com_content\&view=article\&id=1330:estadocontinua-descumprindo-pacto-internacional-de-melhoria-do-sistema-prisional-denunciasingeperon\&catid=34:noticias\&Itemid $=57>$. Acesso em 11 de junho de 2015.
} 
No caso da Penitenciária de Pedrinhas, em resolução de 14 de novembro de $2014^{45}$, emitida pela Corte, considerou-se como essencial "assegurar o acesso de serviços de saúde a pessoas que requeiram atendimento urgente, bem como a pessoas com deficiência mental". No caso do Complexo de Curado houve considerações no mesmo sentido.

Na medida relativa à Penitenciária "Dr. Sebastião Martins Silveira", em Resolução emitida pela em 30 de setembro de 2006, a Corte determinou que o Estado “ mantenha e adote as medidas que sejam necessárias para prover condições de detenção compatíveis com uma vida digna nos centros penitenciários em que se encontram os beneficiários das presentes medidas, o que deve compreender: a) atenção médica necessária, em particular àqueles que padecem de doenças infecto- contagiosas ou se encontram em grave condição de saúde $[\ldots]^{\prime 44}$.

Essas análises permitem aferir que o déficit no acesso à saúde é um problema que marca o sistema prisional do país.

\section{CONCLUSÃO}

Não existem normas no Direito Brasileiro que versem sobre o modo de implementação das determinações da Corte interamericana de Direitos Humanos no país. Assim, percebeu-se que a efetivação dessas medidas está vinculada à vontade política dos diversos agentes envolvidos.

O caso concreto analisado demonstra que os vínculos firmados entre os entes federativos e as instituições brasileiras são frágeis e foram pouco efetivos, alegação confirmada pela calamitosa situação da saúde no presídio Urso Branco.

A análise da questão na saúde no Presídio Urso Branco foi útil no sentido de permitir aferir as dificuldades que o Brasil, como Estado Federativo de dimensões continentais, encontra na efetivação das determinações internacionais.

Ademais, tal análise se prestou a confirmar que a União cometeu um equívoco ao não incluir a gestão do Município de Porto Velho na implementação das melhorias

\footnotetext{
${ }^{45}$ CORTE INTERAMERICANA DE DIREITOS HUMANOS. Resolução de 14 de Novembro de 2014. Medidas Provisórias Solicitadas Pela Comissão Interamericana De Direitos Humanos A Respeito Da República Federativa Do Brasil Caso Do Complexo Penitenciário Pedrinhas. p. 04.

${ }^{46}$ CORTE INTERAMERICANA DE DIREITOS HUMANOS. Resolução de 30 de Setembro de 2006. Medidas Provisórias Solicitadas Pela Comissão Interamericana De Direitos Humanos A Respeito Da República Federativa Do Brasil Caso da Penitenciária "Dr. Sebastião Martins Silveira".
} 
propostas pela Corte na Penitenciária, já que tal gestão, segundo os parâmetros da lei interna, também seria responsável por implementar direitos básicos na penitenciária

Por um lado, percebe-se que "o banho de sangue" que existia na época de início da atuação da Corte foi contido através da vontade política advinda da exposição internacional. Verificou-se, ainda, que há diversos órgãos e instituições brasileiras que estão atentas aos regramentos de direitos humanos internacionais e empreendem esforços para a consolidação desses direitos em âmbito interno, como a SDH e o CNJ. Por outro lado, percebe-se que as decisões encontram dificuldades em se efetivar no âmbito local, já que os gestores dos Estados da União e dos Municípios ainda estão pouco afeitos às questões de Direito Internacional.

De todo modo, as análises suscitam uma indagação: Poderia a criação de uma normatização sobre a implementação das decisões/medidas da Corte Interamericana ser um fator para sua maior efetividade.

\title{
SISTEMA PENITENCIARIO BRASILEÑO Y SISTEMA INTERAMERICANO DE PROTECCIÓN DE LOS DERECHOS HUMANOS: LA ANÁLISIS DEL CASO OSO BLANCO A LA LUZ DEL DERECHO A LA SALUD
}

\author{
Cinthia de Cerqueira Alves \\ Márcia Costa Misi
}

\begin{abstract}
RESUMEN
Este artículo tiene como objetivo evaluar cómo es la puesta en práctica de las decisiones de la Corte Interamericana de Derechos Humanos en Brasil, específicamente en lo que respecta al sistema penitenciario. Para cumplir este objetivo se seleccionó el caso de Urso Branco, sujeto a diversas medidas provisionales dictadas por la Corte. Este caso se refiere a la situación en una prisión ubicada en el Estado de Rondônia que se perpetró graves violaciónes de los derechos humanos, con la aparición de la segunda mayor masacre de la historia carcelaria de Brasil. Con el análisis de los informes emitidos por la Corte Interamericana en relación con el caso anterior, nos encontramos con que una amplia gama de derechos fuera faltó el respeto por el Estado brasileño. Frente a la magnitud de las violaciónes, era necesario elegir un capítulo específico para el análisis: el acceso a la atención de salud en el sistema penitenciario, que sigue siendo un problema no resuelto por el Estado brasileño. Así que hubo acción estatal adoptadas para aplicar las decisiones de la Corte, así como los obstáculos encontrados en el proceso de realización de las disposiciones de este cuerpo frente a la realidad de las peculiaridades del Estado Brasileño.
\end{abstract}


Palavras clave: Derecho internacional. Corte interamericana. Sistema penitenciario brasileño.

\section{REFERÊNCIAS}

BORGES, Nadine. Damião Ximenes: Primeira Condenação do Brasil na Corte interamericana de Direitos Humanos. Rio de Janeiro: Revan, 2009.

COIMBRA, Elisa Mara. Sistema Interamericano de Direitos Humanos: Desafios à implementação das decisões da Corte no Brasil. SUR. Revista Internacional de Direitos Humanos / Sur - Rede Universitária de Direitos Humanos - São Paulo v.10, n.19, nov.2013. p. 59.

COMISSÃO INTERAMERICANA DE DIREITOS HUMANOS. Informe sobre os Direitos Humanos Das Pessoas Privadas de liberdade nas Américas. 2011.

COMISSÃO JUSTIÇA E PAZ DA ARQUIDIOCESE DE PORTO VELHO e JUSTIÇA GLOBAL. Presídio Urso Branco: a Institucionalização da barbárie. Porto Velho: s/e. 2007. Disponível em: $<$ http://www.dhnet.org.br/dados/relatorios/a_pdf/r_jg_ro_urso_branco_2007.pdf> Acesso em 10 de Março de 2014.

CONSELHO NACIONAL DE JUSTIÇA. MUTIRÃO CARCERÁRIO REGIONAL NO PRESÍDIOURSOBRANCO/RONDÔNIA. $2014 . \quad$ p. 26.Disponívelem: $<$ http://www.cnj.jus.br/images/programas/mutiraocarcerario/relatorios /Relatorio_Mutirao_RONDONIA_reduzido.pdf.> . Acesso em: 11 de abril de 2015.

CORTE INTERAMERICANA DE DIREITOS HUMANOS. 2002. Resolução de 18 de Junho de 2002, Medidas Provisórias Solicitadas Pela Comissão Interamericana De Direitos Humanos A Respeito Da República Federativa Do Brasil Caso Da Penitenciária Urso Branco.

MIRANDA, Mariana Almeida Picanço de; CUNHA, José Ricardo. Poder Judiciário Brasileiro e Proteção Dos Direitos Humanos: Aplicabilidade e incorporação das decisões da Corte Interamericana de Direitos Humanos. Rio de Janeiro: Escola de Direito do Rio de Janeiro da Fundação Getúlio Vargas, Centro de Justiça e Sociedade, 2010. 133 p.

ORGANIZAÇÃO DOS ESTADOS AMERICANOS. Documentos básicos em matéria de Direitos Humanos no sistema interamericano. Washington, DC: s/e. 2007.

ORTIGA, Ângela Maria Blatt; CONILL, Leonor Minho. Municipalização Da Saúde: A Trajetória No Estado De Santa Catarina. Revista de Saúde Pública de Santa Catarina. Florianópolis v. 1, n. 1, jan./jul. 2009 p. 27. Disponível em: $<$ http://esp.saude.sc.gov.br/sistemas/revista/index.php/inicio/article/viewFile/5/74>.

PIOVESAN, Flávia. Direitos Humanos e o Direito Constitucional Internacional. 14. ed., rev. e atual. São Paulo : Saraiva, 2013.

RAMOS, André de Carvalho. Curso de Direitos Humanos. São Paulo: Saraiva, 2014. 
SANTOS, Alberto Silva. A internacionalização dos Direitos Humanos e o Sistema Interamericano de Proteção. Belo Horizonte: Arraes editores, 2012.

SINGEPEREON. Estado continua descumprindo Pacto internacional de melhoria do sistema prisional, denuncia Singeperon. Disponível em: http://www.singeperon.com.br/portal/index.php?option=com_content\&view=article\&id =1330:estado-continua-descumprindo-pacto-internacional-de-melhoria-do-sistemaprisional-denuncia. Acesso em 11 de junho de 2015.

VIEIRA, Oscar Vilhena; et al. Implementação das recomendações e decisões do sistema interamericano de direitos humanos no Brasil : institucionalização e política. São Paulo: Direito GV, 2013. (Série pesquisa direito GV).

. Resolução de 29 de Agosto de 2002. Medidas Provisórias Solicitadas Pela Comissão Interamericana De Direitos Humanos A Respeito Da República Federativa Do Brasil Caso Da Penitenciária Urso Branco.

. Resolução de 22 de Abril de 2004. Medidas Provisórias Solicitadas Pela Comissão Interamericana De Direitos Humanos A Respeito Da República Federativa Do Brasil Caso Da Penitenciária Urso Branco.

. Resolução de 07 de Julho de 2004. Medidas Provisórias Solicitadas Pela Comissão Interamericana De Direitos Humanos A Respeito Da República Federativa Do Brasil Caso Da Penitenciária Urso Branco.

. Resolução de 21 de Setembro de 2005. Medidas Provisórias Solicitadas Pela Comissão Interamericana De Direitos Humanos A Respeito Da República Federativa Do Brasil Caso Da Penitenciária Urso Branco.

. Resolução de 02 de maio de 2008. Medidas Provisórias Solicitadas Pela Comissão Interamericana De Direitos Humanos A Respeito Da República Federativa Do Brasil Caso Da Penitenciária Urso Branco.

. Resolução de 17 de Agosto de 2009. Medidas Provisórias Solicitadas Pela Comissão Interamericana De Direitos Humanos A Respeito Da República Federativa Do Brasil Caso Da Penitenciária Urso Branco.

. Resolução de 25 de Novembro de 2009. Medidas Provisórias Solicitadas Pela Comissão Interamericana De Direitos Humanos A Respeito Da República Federativa Do Brasil Caso Da Penitenciária Urso Branco. 